\title{
HUBUNGAN ANTARA INTRINSIC RELIGIOUSNESS, ATTITUDE TOWARD DIGITAL PIRACY, DAN INTENTION TO COMMIT DIGITAL PIRACY
}

\author{
Ari Irawan \\ Universitas Brawijaya \\ ari.irawan@ub.ac.id
}

\begin{abstract}
This study aims to (1) find out the effect of Intrinsic Religiousness on Attitude toward Digital Piracy (2) find out the effect of Intrinsic Religiousness on Intention to Commit Digital Piracy (3) find out the effect of Attitude toward Digital Piracy on Intention to Commit Digital PiracyThe type of research used is associative with a quantitative approach. The population in this study were 2013-2018 students of Universitas Brawijaya who using Microsoft Office and worship in mosques on the main campus of Universitas Brawijaya. The sample used in this study was 115 respondents taken by using purposive sampling and data collection methods using questionnaires. Data analysis used is descriptive statistical analysis and path analysis (path analysis). The data in this study were processed using SPSS. The results of this research show that Intrinsic Religiousness $(x)$ has a significant on Attitude toward Digital Piracy (z) and Intention to Commit Digital Piracy (y), moreover Attitude toward Digital Piracy $(z)$ have a significant effect on Intention to Commit Digital Piracy (y).
\end{abstract}

Keywords:digital piracy; quantitative analysis; social marketing.

\section{PENDAHULUAN}

Beredarnya produk digital membuat perilaku konsumsi masyarakat berubah (Nisaputra, 2017). Seperti yang disampaikan Presiden Joko Widodo bahwa masyarakat tidak hanya mengkonsumsi produk konvensional saja, namun saat ini masyarakat juga mengkonsumsi produk digital baik berupa barang maupun berupa jasa. Perubahan konsumsi masyarakat ini membuat permintaan konsumen akan produk digital meningkat pesat. Produsen produk digital juga meningkat pesat untuk mengimbangi permintaan masyarakat yang tinggi akan produk-produk digital yang diinginkan konsumen.(CNN Indonesia, 2017)

Produk digital dapat dibeli oleh konsumen secara online melalui internet, dikonsumsi secara langsung serta dapat dikonsumsi tanpa takut mengurangi kuantitasnya atau hilang. Pernyataan dari Atasoy dan Morewedge ini secara langsung menunjukkan keunggulan dari produk digital. Meski memiliki beberapa kelebihan, produk digital tidaklah sempurna dan tetap memiliki kelemahan. Kelemahan yang paling menonjol yaitu produk digital sangat rentan terhadap pembajakan. Untuk mendapatkan produk digital bajakan juga tergolong tidak susah karena di internet banyak orang yang telah berhasil membajak produk digital dan mendistribusikannya. Konsumen dapat membeli produk digital dengan harga yang jauh lebih murah dibanding harga asli bahkan beberapa produk bajakan bisa didapat secara gratis (Atasoy dan Morewedge, 2018).

Digital piracy atau di Indonesia biasa disebut dengan pembajakan digital "meliputi menyalin dan/ atau mengunduh sebuah software atau materi digital secara ilegal" (Yoon, 2011). Pembajakan digital ini menjadi perhatian yang cukup serius di tingkat global (Terra, 2016). Yoon (2011) menyatakan bahwa praktik pembajakan digital telah menjadi ancaman serius terhadap perkembangan industri perangkat lunak dan industri media digital. Bila pembajakan digitalterus berlanjut, hal ini tentunya akan merugikan perusahaan yang telah membuat produk digital tersebut. Negara tentu turut dirugikan pula karena akan kehilangan pemasukan negara salah satunya dari pajak produk digital. Data dari Business Software Alliance (BSA, 2018) menunjukan bahwa kerugian yang diakibatkan oleh pembajakan digital secara global mencapai angka 46,3 miliar dolar Amerika. 
Sedangkan di Indonesia berdasarkan laporan dari Masyarakat Indonesia Anti Pemalsuan (MIAP) kerugian negara menembus angka 2,1 triliun rupiah (Bekraf, 2019). Untuk mengindari kerugiankerugian yang terjadi, pemerintah membuat peraturan untuk mengurangi pembajakan digital. Menurut hukum yang berlaku di Indonesia, pembajakan digitaldiatur dalam Undang-Undang Republik Indonesia Nomor 28 Tahun 2014 Tentang Hak Cipta. Undang-Undang terkait hak cipta ini sengaja dibuat untuk mengurangi tingkat pembajakan yang ada di Indonesia. Untuk mengurangi tingkat pembajakan, dalam Undang-Undang ini diberlakukan ancaman pidana serta denda bagi pihak yang melanggar Undang-Undang ini. Ancaman yang diberikan dalam Undang-Undang ini tergolong berat. Undang-Undang Republik Indonesia Nomor 28 Tahun 2014 Tentang Hak Cipta menyatakan "Barangsiapa yang melakukan tindakan pembajakan akan dikenakan pidana paling lama 10 tahun dan/atau denda sebesar Rp4.000.000.000,- (empat milyar rupiah)."

Selain itu, agama Islam juga mengatur tentang hak cipta. Bila memandang hukum hak cipta dari sudut pandang islam,di Indonesia hak cipta diatur dalam Fatwa Komisi Fatwa Majelis Ulama Indonesia Nomor 1 Tahun 2003 Tentang Hak Cipta. Fatwa tentang hak cipta ini menetapkan bahwa: Dalam hukum Islam, Hak Cipta dipandang sebagai salah satu huquq maliyyah (hak kekayaan) yang mendapat perlindungan hukum (mashun) sebagaimana mal (kekayaan).Hak Cipta yang mendapat perlindungan hukum Islam sebagaimana dimaksud angka 1 tersebut adalah hak cipta atas ciptaan yang tidak bertentangan dengan hukum Islam. Sebagaimana mal, Hak Cipta dapat dijadikan obyek akad (al-ma'qud 'alaih), baik akad mu'awadhah (pertukaran, komersial), maupun akad tabarru'at (nonkomersial), serta diwaqafkan dan diwarisi. Setiap bentuk pelanggaran terhadap hak cipta, terutama pembajakan, merupakan kezaliman yang hukumnya adalah haram. Dari fatwa tersebut dapat diketahui bahwa hak cipta diatur dan dilindungi dalam Islam. Berdasarkan Fatwa Majelis Ulama Indonesia Nomor 1 Tahun 2003 Tentang Hak Cipta segala tindakan pelanggaran serta pembajakan merupakan tindakan tidak terpuji yang zalim dan diharamkan.

Indonesia merupakan negara beragama yang dibuktikan dengan ideologi Pancasila di mana sila pertama berbunyi Ketuhanan yang Maha Esa (UUD RI, 1945). Hal ini menunjukkan bahwa agama merupakan hal yang dianggap sangat penting di Indonesia. Lu dan Lu (2010) dalam penelitiannya menemukan bahwa agama berperan signifikan dalam kehidupan masyarakat Indonesia. Terdapat enam agama yang diakui di Indonesia yaitu Islam, Kristen, Katholik, Hindu, Budha dan Konghucu. Di antara keenam agama yang diakui di Indonesia, Islam merupakan agama mayoritas yang paling banyak dianut masyarakat Indonesia. Indonesia juga menyandang status sebagai negara dengan jumlah penduduk muslim terbesar di dunia (Katadata, 2016). Suryadinata, Nurvidya dan Ananta (2003) dalam (Casidy, Phau, dan Lwin, 2016) menyatakan bahwa Indonesia merupakan negara dengan tingkat religius yang tinggi. Sebagai negara mayoritas muslim dengan tingkat religius yang tinggi, seharusnya masyarakat Indonesia menghindari pembajakan digital yang merupakan tindakan tidak terpuji yang diharamkan.

Indonesia memang dipandang sebagai negara yang religius, namun sayangnya terdapat sebuah fakta yang mengejutkan. Pembajakan digital yang terjadi secara global menunjukan bahwa pembajakan terbesar terdapat di wilayah Eropa Timur dan Eropa Tengah serta wilayah Asia Pasifik. (BSA, 2018). Data dari Business Software Alliance (2018) juga menunjukkan untuk wilayah Asia Pasifik, per tahun 2017 Indonesia termasuk dalam tiga besar negara dengan pembajakan digital yang tinggi. Fakta bahwa Indonesia termasuk dalam tiga besar negara dengan pembajakan digital yang tinggi tentu bertentangan dengan predikat yang diperoleh Indonesia sebagai negara religius. Predikat negara religius yang dikemukakan oleh Suryadinata, Nurvidya dan Ananta (2003) dalam (Casidy, Phau, dan Lwin, 2016) ternyata masih belum bisa menurunkan pembajakan digital yang ada di Indonesia.

Penelitian ini mempunyai tujuan secara teoritis sekaligus secara praktis. Secara teoritis penelitian ini akan memberikan gambaran teori pemasaran sosial (social marketing) yang masih belum banyak menjadi perhatian dari peneliti dari disiplin ilmu pemasaran, terutama hubungannya dengan relijiusitas. Kemudian secara praktis, dengan mengetahui alasan pembajakan digital yang dilakukan oleh konsumen diharapkan para pemangku kepentingan bisa memberikan solusi terbaik untuk mengurangi masalah ini. 


\section{KAJIAN PUSTAKA DAN HIPOTESIS}

Pemasaran sosial atau social marketing mempunyai tujuan untuk mempengaruhi perilaku individu yang di harapkan dapat berdampak pada perubahan masyarakat dan juga individu tersebut (Lee dan Kotler, 2019). Perubahan yang di harapkan dari audiens terdiri dari 4 hal; menerima sebuah perilaku baru, menolak perilaku yang tidak diharapkan, memodifikasi perilaku tertentu, dan mengabaikan perilaku lama yang tidak diinginkan. Perilaku pembajakan digital termasuk pada perilaku yang harus di tolak dengan cara demarketing (Irawan, 2017), dengan menerapkan fear appears (Irawan et al, 2018) atau dapat juga di modifikasi dengan menerapkan pendekatan orientasi keagamaan atau religiousness orientation.

\section{Religiousness Orientation}

Batson dan Ventis (1982) menyatakan bahwa "Religiousness Orientation is the term employed by psychologists to refer to the way in wich a person practices or lives out his or her religious beliefs and values" yang artinya adalah istilah yang digunakan oleh para psikolog untuk mengarahkan kepada bagaimana seseorang mempraktikkan atau hidup dengan keyakinan dan nilai-nilai agamanya. Religiousness Orientation menjadi pandangan seseorang tentang bagaimana menjalani kehidupan agamanya, apakah menjadikan agama sebagai pedoman hidup, atau hanya menggunakan agama untuk kepentingan pribadi.

Menurut Allport dan Ross (1967) untuk memperjelas Religiousness Orientation Scale, dapat dikarakterisasi dalam dua tipe ideal, yaitu Intrinsic Religiousness dan Extrinsic Religiousness. Seseorang dengan Intrinsic Religiousness akan menghayati agamanya tanpa didasari oleh kepentingan pribadi baik secara personal maupun kepentingan pribadi secara sosial. Berbeda dengan Intrinsic Religiousness (IR) seseorang dengan Extrinsic Religiousness cenderung menggunakan agama untuk tujuan mereka sendiri.

Kirkpatrick (1988) dalam Arli dan Tjiptono (2014) sesuai dengan ukuran dari Allport dan Ross (1967) membagi Extrinsic Religiousness kedalam dua kategori berbeda yaitu Extrinsic Social Religiousness dan Extrinsic Personal Religiousness. Menurut Kirkpatrick dan Hood (1990)Extrinsic Social Religiousness "involving the use of religion as a means toward social gain" yang artinya adalah melibatkan penggunaan agama sebagai sarana menuju keuntungan social. Berbeda dengan Extrinsic Social Religiousness, menurutKirkpatrick dan Hood (1990) Extrinsic Personal Religiousness "involving the use of religion as a means toward gaining comfort, security, and protection" yang artinya melibatkan penggunaan agama sebagai sarana untuk mendapatkan kenyamanan, keamanan, dan perlindungan.

\section{Attitude toward Digital Piracy}

Attitude toward Digital Piracy (AtDP) bisa dilihat melalui Theory of Reasoned Action (TRA) yang dikemukakan oleh Fishbein dan Ajzen (1975) dalam (Cronan dan Al-Rafee, 2008). Theory of Reasoned Action didasarkan bahwa dua faktor kunci yang mempengaruhi perilaku manusia adalah attitude dan subjective norms. Attitude menempatkan orang dalam kerangka pemikiran mengenai menyukai atau tidak menyukai sesuatu, mengenai mendekati atau menjauhinya. Menurut Fishbein dan Ajzen (1991) Attitude toward Digital Piracy dapat didefinisikan menjadi perasaan individu positif atau negatif tentang perilaku pembajakan digital. Untuk mengukur attitude menggunakan evaluation outcomes yang merupakan sebuah evaluasi terhadap hal-hal atau kunsekuensi (positif-negatif, favorable-unfavorable) (Yogatama, 2013).

\section{Intention to Commit Digital Piracy}

Intention to Commit Digital Piracy (ItCDP) di turunkan dari teori Ajzen (1991) menggunakan Theory Planned Behaviour yang merupakan ekstensi dari Theory of Reasoned yang dikemukakan oleh Fishbein dan Ajzen (1975). Berdasarkan Theory Planned Behaviour, perilaku aktual seseorang secara langsung dipengaruhi oleh behavioral intention mereka, dan secara bersama dipengaruhi pula oleh 
Ari Irawan. Hubungan antara Intrinsic Religiousness, Attitude toward Digital Piracy, dan Intention to Commit Digital Piracy

attitude, subjective norms dan perceived behaviour control yang dirasakan terhadap pelaksanaan perilaku tersebut (Yoon, 2011). Theory Planned Behaviour ini merupakan teori yang biasa digunakan para peneliti untuk meneliti minat seseorang untuk melakukan perbuatan yang berhubungan dengan etika. Theory Planned Behaviour ini merupakan model untuk minatyang diteliti dengan baik dan telah terbukti berhasil dalam memprediksi dan menjelaskan perilaku di berbagai domain (Lin et al., 1999) dalam (Yoon, 2011). Hubungan antar variabel dalam penelitian ini dapat dilihat di gambar 1.

\section{Hipotesis}

H1: IR (X) berpengaruh signifikan terhadap $\operatorname{AtDP}(\mathrm{Z})$.

H2: IR (X) berpengaruh signifikan terhadap $\operatorname{ItCDP}(\mathrm{Y})$.

H3: AtDP (Z) berpengaruh signifikan terhadap ItCDP (Y).

\section{METODE PENELITIAN}

Jenis penelitian ini adalah penelitian kuantitatif asosiatif. Lokasi penelitian dilakukan adalah lingkungan Universitas Brawijaya Malang. Kuesioner tertulis dengan sampel sejumlah 115 orang responden mahasiswa Universitas Brawijaya pengguna Microsoft Office yang dipilih secara proporsional mewakili jumlah mahasiswa masing-masing fakultas. Data diperoleh dengan menyebarkan kuesioner secara langsung kepada mahasiswa setelah melakukan ibadah shalat pada masjid atau mushalla fakultas. Dalam kuesioner berisi data demografis, pernyataan dengan skala likert 1-5 dan pertanyaan terbuka di akhir kuesioner. Variabel IR di ukur dengan 7 butir pertanyaan, variabel ItCDP dengan 5 butir pertanyaan dan AtDP dengan 4 butir pertanyaan. Analisis data menggunakan analisis jalur untuk mengetahui hubungan antara ketiga variabel yang diteliti, dan analisis deskriptif yang menggambarkan profil responden.

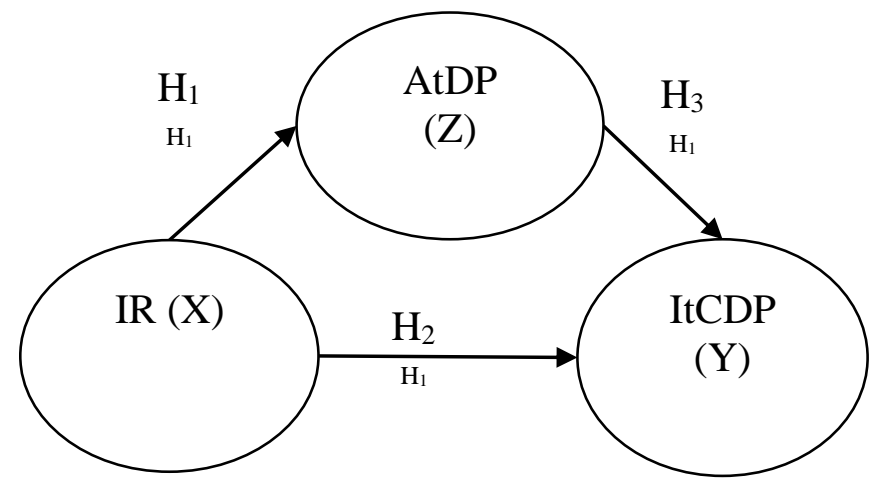

Gambar 1. MODEL HIPOTESIS

\section{HASIL DAN PEMBAHASAN}

Dari data demografis responden di tabel 1 didapatkan bahwa jenis kelamin perempuan lebih mendominasi sebesar $54 \%$, dengan sebagian besar responden berusian antara 19-20 tahun sejumlah 54 responden $(46 \%)$. Sedangkan untuk uang saku perbulan dari responden sebagian besar ada pada rentang satu sampai dua juta rupiah dan kurang dari Rp1.000.000,- dengan total persentase sebesar $87 \%$.

Keseluruhan hasil analisis jalur dan hubungan antara variabel dalam terdapat pada gambar 2 yang menunjukkan hasil rekapitulasi dari pengaruh $I R$ terhadap AtDP dan ItCDP. Analisis jalur dapat memberikan informasi mengenai pengaruh langsung, pengaruh tidak langsung dan pengaruh total hubungan atar variabel yang diteliti. Pada hubungan $I R(\mathrm{X})$ dengan ItCDP (Y) terdapat dugaan variabel $A t D P(Z)$ sebagai variabel intervening dijelaskan pada tabel 2.

Perhitungan pada tabel 2 menunjukkan bahwa variabel Attitude toward Digital Piracy berperan sebagai mediator parsial karena variabel Intrinsic Religiousness dapat berpengaruh signifikan terhadap Intention toward Digital Piracy tanpa melalui variabel Attitude toward Digital Piracy.Hasil 
perhitungan tersebut menerangkan bahwa kontribusi model untuk menjelaskan hubungan struktural dari ketiga variabel yang diteliti adalah sebesar 21,7\%. Sisa dari hasil tersebut adalah sebesar 78,3\% disejalaskan oleh variabel lain yang tidak terdapat dalam model penelitan ini.

Tabel 1

DATA DEMOGRAFIS RESPONDEN

\begin{tabular}{lrr}
\hline \multicolumn{1}{c}{ Variabel } & Frekuesi & Persentase \\
\hline Jenis kelamin & & \\
$\quad$ Laki-laki & 53 & 46 \\
$\quad$ Perempuan & 62 & 54 \\
Total & 115 & 100 \\
Usia (tahun) & & \\
17-18 & 18 & 14 \\
$19-20$ & 54 & 46 \\
$21-22$ & 35 & 31 \\
$>=23$ & 10 & 9 \\
Total & 115 & 100 \\
Uang saku per bulan (rupiah) & & \\
$<=1.000 .000$ & 44 & 38 \\
$1.000 .001-2.000 .000$ & 56 & 49 \\
$2.000 .001-3.000 .000$ & 10 & 9 \\
$>=3.000 .000$ & 5 & 4 \\
Total & 115 & 100 \\
\hline
\end{tabular}

Sumber: Data primer diolah, 2019

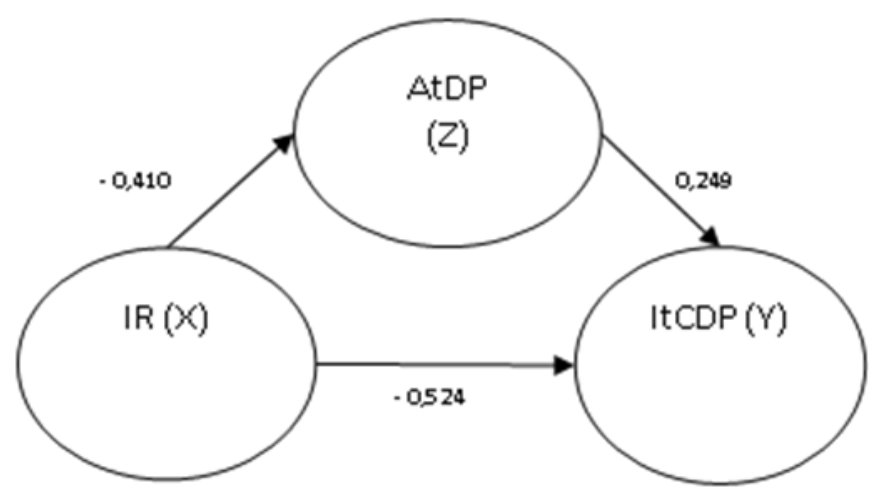

Gambar 2. HASIL ANALISIS JALUR

Tabel 2.

HASIL PERHITUNGAN KOEFISIEN JALUR MODEL PENELITIAN

\begin{tabular}{lccccc}
\hline \multicolumn{1}{c}{$\begin{array}{l}\text { Variabel } \\
\text { Penelitian }\end{array}$} & Attitude toward Digital Piracy $(\mathbf{Z})$ & \multicolumn{3}{c}{ Intention to Commit Digital Piracy (Y) } \\
\cline { 2 - 6 } & Direct & Total & Direct & Indirect & Total \\
\hline $\begin{array}{l}\text { Intrinsic } \\
\text { Religiousness }(\mathrm{X})\end{array}$ & $-0,410$ & $-0,410$ & $-0,524$ & $-0,134$ & $-0,654$ \\
\hline $\begin{array}{l}\text { Attitude toward } \\
\text { Digital Piracy } \\
\text { (Z) }\end{array}$ & & & 0,249 & & 0,249 \\
\hline $\mathrm{n}=115$ & & & & \\
$\mathrm{R}$ Square $=0,217$ & & & & & \\
\hline
\end{tabular}

Sumber: Data primer diolah, 2019

Pengaruh Intrinsic Religiousness (X) terhadap Attitude toward Digital Piracy (Z)

Hasil penelitian menunjukkan semakin relijius seseorang maka akan memiliki kecenderungan sikap untuk menentang terhadap pembajakan digital. Hasil ini didukung oleh penelitian yang telah 
dilakukan oleh Arli et al. (2017), menyatakan bahwa Intrinsic Religiousness memainkan peran penting dalam mempengaruhi sikap anak usia muda terhadap pembajakan digital. Semakin tinggi Intrinsic Religiousness seseorang, maka Sikap seseorang terhadap Pembajakan Digital akan menentang. Sikap responden yang relijius (ditunjukkan dengan kepatuhan melaksanan shalat) secara fitrah memang menentang dan ini terbukti dari responden mengakui bahwa dengan membajak sama dengan mencuri hasil karya orang lain.

Pembajakan digital dianggap sebagai tindakan tidak bermoral yang bertentangan dengan agama yang dijalani. Demikian juga penelitian lain oleh Casidy, Phau, and Lwin, (2016); Lavrič and Flere, (2011) yang menyatakan bahwa orang dengan relijiusitas yang tinggi memiliki sikap yang lebih kuat untuk menentang pembajakan digital dibandingkan dengan seseorang yang memiliki relijiusitas yang rendah. Hal ini mengkonfirmasi teori dariAllport and Ross (1967) bahwa seseorang dengan Intrinsic Religiousness adalah seorang true believer atau orang beriman sejati. Orang beriman sejati akan memiliki pandangan hidup sesuai dengan ajaran agamanya sehingga orang dengan Intrinsic Religiousness akan memiliki sikap dimana tidak mendukung pembajakan digital dan menganggap pembajakan adalah hal yang tercela. Dengan kata lain, seseorang dengan Intrinsic Religiousness yang tinggi akan menentang Digital Piracy. Pembajakan dianggap sebagai perilaku tercela yang bertentangan dengan ajaran agama. Pandangan seorang yang beriman sejati akan sejalan dengan pandangan agama yang melarang pembajakan.

\section{Pengaruh Intrinsic Religiousness (X) terhadap Intention to Commit Digital Piracy (Y)}

Hasil yang diperoleh menunjukkan ketika semakin religius seseorang maka minat untuk melakukan pembajakan digital semakin menurun. Fakta ini didukung oleh penelitian yang telah dilakukan oleh Arli et al. (2017) yang menyatakan bahwa Intrinsic Religiousness turut memberikan peran dalam mempengaruhi Intention to Commit Digital Piracy anak usia muda. Semakin tinggi Intrinsic Religiousness seseorang, minat seseorang untuk melakukan pembajakan digital akan semakin menurun. Hal ini terbukti dari hasil pertanyaan terbuka ada responden yang menggunakan software digital asli karena khawatir hasil kerjanya tidak barakah jika menggunakan yang bajakan.

Penelitian dari Pamungkas (2014);Casidy, Phau, and Lwin (2016); Banazadeh et al (2019)juga turut mendukung hasil penelitian ini dimana Intrinsic Religiousness berpengaruh negatif terhadap perilaku negatif lain seperti dalam kecurangan pencatatan akuntansi dan konsumsi nikotin. Berdasarkan hasil penelitian dan penelitian terdahulu bahwa terdapat pengaruh negatif signifikan antara Intrinsic Religiousness terhadap Intention to Commit Digital Piracy. Pengaruh negatif menandakan bahwa responden menyadari bahwa pembajakan digital merupakan perbuatan dosa yang bertentangan dengan agama.Seseorang dengan Intrinsic Religiousness yang tinggi akan memiliki Intention to Commit Digital Piracy yang rendah.

\section{Pengaruh Attitude toward Digital Piracy (Z) terhadap Intention to Commit Digital Piracy (Y)}

Hubungan antara sikap (attitude) mendukung pembajakan digital dan minat (intention) seseorang tersebut untuk melakukan pembajakan digital menunjukkan hubungan pengaruh yang positif.Sesuai dengan penelitian terdahulu olehYoon (2011);Morton and Koufteros (2008); danArli et al. (2017)yang menyatakan bahwa Attitude toward Digital Piracy merupakan faktor anteseden yang signifikan dari Intention to Commit Digital Piracy. Pengaruh positif menandakan bahwa seseorang yang memiliki sikap mendukung terhadap pembajakan digital Microsoft Office akan memiliki minat untuk melakukan pembajakan digital Microsoft Office. Ketika seseorang mendukung pembajakan digital maka minat untuk melakukan pembajakan digital juga akan semakin meningkat.

Data demografis menunjukkan bahwa sebagian besar responden (97 dari 115 responden) menggunakan software Microsoft Office bajakan. Dimana hasil ini bertentangan dengan penelitian yang menunjukkan bahwa Intrinsic Religiousness berpengaruh negatif signifikan terhadap variabel Attitude toward Digital Piracy dan Intention to Commit Digital Piracy. Meskipun responden memiliki Intrinsic Religiousness yang tinggi, bersikap menentang pembajakan digital serta mempunyai minat yang rendah untuk menggunakan Microsoft Office bajakan, dengan alasan harga yang mahal responden melakukan perbuatan yang bertentangan dengan agama. Berdasarkan pertanyaan terbuka, 
hal yang paling utama mempengaruhi responden masih melakukan pembajakan digital adalah harga software Microsoft Office yang dipandang responden mahal. Dimana rata-rata responden hanya mendapatkan kurang dari 2 juta rupiah perbulan (tabel 1), sedangkan biaya hidup mahasiswa S1 berkisar 1-3 juta rupiah perbulan (Aminudin, 2018). Berdasarkan fakta tersebut diketahui bahwa agama tidak selamanya dapat menjadi pembatas/penghalang seseorang untuk tidak melakukan perbuatan dosa atau perilaku yang dilarang oleh agamanya seperti pembajakan digital.

\section{KESIMPULAN}

Hasil penelitian menunjukkan bahwa meskipun responden memiliki Intrinsic Religiousness yang kuat, memiliki sikap menentang terhadap pembajakan digital dan memiliki minat yang rendah untuk tetap menggunakan software Microsoft Office bajakan di waktu yang akan datang, namun saat dilakukan penelitian responden masih melakukan perbuatan dosa yang bertentangan dengan ajaran agama yaitu masih menggunakan software Microsoft Office bajakan. Agama tidak selamanya dapat menjadi pembatas/penghalang seseorang untuk tidak melakukan perilaku yang dilarang oleh agamanya seperti contohnya pembajakan digital meskipun seseorang tersebut mengetahui bahwa perilaku tersebut dilarang oleh agama. Hal ini terkait erat dengan responden yang masih mahasiswa dan dengan penghasilan yang rendah, sehingga keberatan untuk membeli software legal yang harganya relatif mahal.

Bagi peneliti selanjutnya disarankan untuk mempertimbangkan masalah harga sebagai variabel lain yang mempengaruhi keputusan untuk melakukan pembajakan digital. Selain itu untuk peneliti memberi saran untuk meneliti tentang kereligiusan terhadap pembajakan digital dengan menggunakan metode kualitatif untuk mengetahui secara mendalam perilaku pembajakan digital ini. Saran praktis untuk yaitu kepada pihak universitas bisa bekerja sama dengan pihak Microsoft Office supaya mahasiswa Universitas Brawijaya dapat mengakses Microsoft Office 365 Education secara legal. Universitas Brawijaya tidak cukup hanya berkerja sama saja, namun perlu mensosialisasikan dan memberikan informasi mengenai Microsoft Office 365 Education.

\section{DAFTAR PUSTAKA}

Ajzen, Icek. 1991. The theory of planned behavior. Organizational behavior and human decision processes, 50(2), 179-211.

Allport, Gordon W, and J Michael Ross. 1967. Personal religious orientation and prejudice. Journal of Personality and Social Psychology 5(4): 432-43.

Aminudin, M. 2018. "Mau Kuliah Di Malang? Ini Estimasi Biaya Hidup Ala Mahasiswa",diakses pada tanggal 1 September 2019. https://news.detik.com/berita/d-4105060/mau-kuliah-dimalang-ini-estimasi-biaya-hidup-ala-mahasiswa.

Arli, Denni, and Fandy Tjiptono. 2014. The end of religion? Examining the role of religiousness, materialism, and long-term orientation on consumer ethics in indonesia. Journal of Business Ethics 123(3): 385-400.

Arli, Denni, Krzysztof Kubacki, Fandy Tjiptono, and Sebastian Morenodiez. 2017. Religiousness and digital piracy among young consumers in an emerging market. Young Consumers 18(1): 40-53.

Atasoy, Ozgun, and Carey K. Morewedge. 2018. Digital goods are valued less than physical goods. Journal of Consumer Research 44(6): 1343-57.

Batson, C. D., \& Ventis, W. L. .1982. The religious experience: A social-psychological perspective. Oxford University Press, USA. 
Ari Irawan. Hubungan antara Intrinsic Religiousness, Attitude toward Digital Piracy, dan Intention to Commit Digital Piracy

Bekraf.go.id. 2019. "Indonesia Rugi Triliunan Rupiah Akibat Pembajakan" di akses pada 28 April 2020 dari https://www.bekraf.go.id/berita/page/8/indonesia-rugi-triliunan-rupiah-akibatpembajakan

BSA. 2018. Software Management: Security Imperative, Business Opportunity.

Casidy, Riza, Ian Phau, and Michael Lwin. 2016. Religiosity and digital piracy: an empirical examination. Services Marketing Quarterly 37(1): 1-13.

CNNIndonesia.com, 2017. "Jokowi: Pola Perniagaan Sudah Bergeser di Era Digital” di akses $\begin{array}{lllll}\text { pada tanggal } & 11 & \text { November } & 2019 & \text { dari }\end{array}$ https://www.cnnindonesia.com/ekonomi/20170920153329-92-242980/jokowi-polaperniagaan-sudah-bergeser-di-era-digital

Cronan, Timothy Paul, and Sulaiman Al-Rafee. 2008. Factors that influence the intention to pirate software and media. Journal of Business Ethics 78(4): 527-45.

Hasanah, Neneng Uswatun. 2017. "Selain Penambahan Pendatang, Mahasiswa Juga Punya Sumbangan Lain Ke Kota Malang, Yaitu", diakses pada Tanggal 15 Desember 2018https://suryamalang.tribunnews.com/2017/04/01/selain-penambahan-pendatangmahasiswa-juga-punya-sumbangan-lain-ke-kota-malang-yaitu.

Irawan, Ari, Adil, F., \& Kholid, M. M. "The Influence Of Fear Appeals On Customer's Motivation To Buy Cigarettes: Survey Conducted To Juveniles Aged 13-19 Years Old In Malang City." Russian Journal of Agricultural and Socio-Economic Sciences (June 2018), 165-168

Irawan, Ari, Supriono, \& Luqman, A. A. "Demarketing Of Cigarette Consumption Among Adolescents Through Family Influence And Fear Appeals."Eurasia: Economics \& Business 3 (21), 77-85

Katadata.co.id. 2016. "Indonesia, Negara Berpenduduk Muslim Terbesar Dunia.” diakses pada Tanggal $11 \quad$ November 2019 dari https://databoks.katadata.co.id/datapublish/2016/11/11/indonesia-negara-berpenduduk-muslimterbesar-dunia

Kirkpatrick, Lee A, and Ralph W Hood. 1990. Intrinsic-extrinsic religious orientation: the boon or bane of contemporary psychology of religion? Journal for Scientific Study of Religion 29(4): 442-62.

Lavrič, Miran, and Sergej Flere. 2011. Intrinsic religious orientation and religious rewards: an empirical evaluation of two approaches to religious motivation. Rationality and Society 23(2): 217-33.

Lee, Nancy, \& Kotler, Philip. 2019. Social marketing: behavior change for social good. SAGE Publications.

Lu, Long-Chuan, and Chia-Ju Lu. 2010. Moral philosophy, materialism, and consumer ethics: an exploratory study in indonesia. Journal of Business Ethics 94(2): 193-210.

Morton, Neil A, and Xenophon Koufteros. 2008. Intention to commit online music piracy and its antecedents: an empirical investigation neil. Psychology Press 15: 491-512.

Nisaputra, Rezkiana. 2017. "Jokowi: Pola Konsumsi Masyarakat Bergeser Ke Online", diakses pada Tanggal 11 November 2018 dari http://infobanknews.com/jokowi-pola-konsumsi-masyarakatbergeser-ke-online/ 
Pamungkas, Imang Dapit. 2014. Pengaruh religiusitas dan rasionalisasi dalam mencegah dan mendeteksi kecenderungan kecurangan akuntansi. Jurnal Ekonomi dan Bisnis 15(2): 48-59.

Permana, Rizky Wahyu. 2016. "Malang Sebagai Kota Pendidikan Sejak Masa Hindia Belanda" diakses pada Tanggal 11 November 2018 dari https://malang.merdeka.com/kabarmalang/malang-sebagai-kota-pendidikan-sejak-masa-hindia-belanda-160502n.html

Savitri, Ayunda Widyastuti. 2016. "Maarif Institute Klarifikasi Soal Penelitian Indeks Kota Islami" diakses pada Tanggal 12 November 2018 dari https://news.detik.com/berita/d-3221194/maarifinstitute-klarifikasi-soal-penelitian-indeks-kota-islami

Terra, Antoni. 2016. Copyright law and digital piracy: an econometric global cross-national study. North Carolina Journal of Law \& Technology 18(1).

UUD RI. 1945. Undang-undang Dasar Republik Indonesia.

Yogatama, Leo Agung Manggala. 2013. Analisis pengaruh attitude, subjective norm, dan perceived behavior control terhadap intensi penggunaan helm saat mengendarai motor pada remaja dan dewasa muda di jakarta selatan. Jurnal PESAT 5: 8-9.

Yoon, Cheolho. 2011. Theory of planned behavior and ethics theory in digital piracy: an integrated model. Journal of Business Ethics 100(3): 405-17. 